This is a revised personal version of the text of the final journal article, which is made available for scholarly purposes only, in accordance with the journal's author permissions. The full citation is:

Jiang Y., Heaven S., Banks C. J. (2012) Strategies for stable anaerobic digestion of vegetable waste. Renewable Energy 44(2012) 206-214.

DOI: 10.1016/i.renene.2012.01.012

\title{
Strategies for stable anaerobic digestion of vegetable waste
}

\section{Author names and affiliations}

Y. Jiang, S. Heaven, C. J. Banks

Faculty of Civil Engineering and the Environment, University of Southampton, Southampton, SO17 1BJ, UK

\section{Corresponding author}

\section{S. Heaven}

Faculty of Civil Engineering and the Environment, University of Southampton, Southampton, SO17 1BJ, UK

Tel +44 (0)2380 592856, Fax +44 (0)2380 677519, e-mail SH7@ soton.ac.uk)

\begin{abstract}
International trade and the market demand for pre-prepared agricultural produce is not only increasing the total quantity of waste agricultural biomass but also centralising its availability, making it potentially useful for energy production. The current work considers the suitability of vegetable trimmings and rejects from high-value produce air-freighted between Africa and Europe as a feedstock for anaerobic digestion. The physical and chemical characteristics of a typical mixed vegetable waste of this type were determined and the theoretical energy yield predicted and compared to experimentally-determined calorific values, and to the energy recovered through a batch biochemical methane potential test. A semi-continuous digestion trial was then carried out with daily feed additions at different organic loading rates (OLR). At an OLR of $2 \mathrm{~g} \mathrm{VS} \mathrm{L}^{-1}$ day $^{-1}$ the substrate gave a methane yield of $0.345 \mathrm{~L} \mathrm{~g} \mathrm{~g}^{-1} \mathrm{VS}$ added with VS destruction $81.3 \%$, and showed that $76.2 \%$ of the measured calorific value of the waste could be reclaimed as methane. This was in good agreement with the estimated energy recovery of $68.6 \%$ based on reaction stoichiometry, and was $99 \%$ of the biochemical methane potential (BMP). Higher loading rates reduced the specific methane yield and energy conversion efficiency, and led to a drop in digester $\mathrm{pH}$ which could not be effectively controlled by alkali additions. To maintain digester stability it was necessary to supplement with additional trace elements including tungsten, which allowed loading rates up to $4 \mathrm{~g} \mathrm{VS} \mathrm{L}^{-1} \mathrm{day}^{-1}$ to be achieved. Stability was also improved by addition of yeast extract (YE), but the higher gas yield obtained was as a result of the contribution made by the YE and no synergy was shown. Co-digestion using card packaging and cattle slurry as co-substrates also proved to be an effective means of restoring and maintaining stable operating conditions.
\end{abstract}

Keywords Anaerobic digestion, Co-digestion, Trace elements, Vegetable waste, Tungsten 
Fruit and vegetable wastes (FVW) are characterised by a high percentage of moisture $(>80 \%)$, high organic content (volatile solids $>95 \%$ of total solids) and are readily biodegraded, and are therefore suited to energy recovery through anaerobic digestion $[1,2]$. Gunaseelan [3] reviewed the data on anaerobic digestion of different types of fruit and vegetable waste, and concluded that the specific methane yield of FVW is very high compared to other municipal solid wastes. A number of studies, however, have indicated problems and limitations in the anaerobic digestion of this material. Knol et al. [4] reported the results of a 90-day experiment using a mixed waste of apples, asparagus, carrots, green peas, French beans, spinach and strawberries from a canning factory. Digestion was in mesophilic conditions at organic loading rates (OLR) between 0.80-1.60 g volatile solids (VS) $\mathrm{L}^{-1}$ day $^{-1}$ with a 32-day hydraulic retention time (HRT), and produced average biogas yields of $0.30-0.58 \mathrm{~L} \mathrm{~g}^{-1}$ VS. Digestion of some of these materials showed instability, and in these cases remedial measures were introduced which included alkali addition, feed interruption and mixing with a nitrogen-rich supplement. In a similar study, Mata-Alvarez et al. [5] reported on the performance of a mesophilic single-stage stirred digester for the treatment of a mixture of fruit and vegetable wastes from a large food market, and found the maximum OLR that could be achieved was $<3 \mathrm{~g} \mathrm{VS} \mathrm{L}^{-1}$ day $^{-1}$. Lane [6] also reported from experiments using completely mixed digesters with a FVW input that a loading above $4 \mathrm{~g}$ VS $\mathrm{L}^{-1}$ day ${ }^{-1}$ caused a fall in $\mathrm{pH}$, lower gas yield and increased $\mathrm{CO}_{2}$ content. These studies suggested that there may be some instability in the anaerobic digestion of FVW at high OLR.

It is known that carbohydrate-rich substrates such as FVW are fast producers of volatile fatty acids (VFAs) [7], and may therefore have a tendency to accumulate VFA which can lead to acidity, low $\mathrm{pH}$ and process inhibition. The organic fraction of fruit and vegetable waste typically includes about $75 \%$ sugars and hemicelluloses, 9\% cellulose and 5\% lignin $[8,9]$. Although rich in energy-yielding compounds this may not be a well-balanced mix for anaerobic digestion. Maintaining a suitable carbon to nitrogen ratio is essential for sustainable digestion, with the optimum in the range of 25-30 [10]. In the case of feedstocks with an unfavourable $\mathrm{C} / \mathrm{N}$ ratio, studies suggest that co-digestion with other substrates that have complementary nutrient characteristics can improve process performance [11].

In an early study by Lane [12], performance of a laboratory-scale digester treating residuals from fruit and vegetable processing was improved after the addition of a trace elements solution containing $\mathrm{Fe}, \mathrm{Zn}, \mathrm{Mn}, \mathrm{Cu}$ and $\mathrm{Mo}$. The conversion percentage for organic solids increased from 88 to $96 \%$, with a corresponding increase in $\mathrm{CH}_{4}$ content of the biogas. Other studies on digestion of potato process waste [13] and on a mixture of fruits, vegetables, meats and fried foods [14] have also suggested improved stability and performance after supplementation with trace elements ( $\mathrm{Fe}, \mathrm{Cu}, \mathrm{Zn}, \mathrm{Mn}, \mathrm{Mo}, \mathrm{Co}, \mathrm{Al}$ and $\mathrm{Se}$ ). Supplementation of essential trace elements has been shown to be important to maintain and even stimulate the digestion process in a number of studies $[15,16,17,18,19,20,21]$. This dependence can be explained by the fact that essential enzymes required for anaerobic biochemical reactions contain metals such as cobalt, nickel, iron, zinc, molybdenum and tungsten, in the form of coenzymes and cofactors. The roles of trace elements in various enzymes involved in anaerobic digestion have been reviewed in detail in several publications [22, 23]. Information on the specific trace element requirements for anaerobic digestion of vegetable waste is limited, however. 
The purpose of the current study was to assess the energy yield and suitability for digestion of a mixture of vegetable wastes. The waste is derived from high-value products grown in Kenya for export to Europe, which are first sorted and trimmed before being crated for air freight. This process generates considerable amounts of waste, as any sub-standard items are also rejected, and cannot be re-distributed for consumption for reasons of hygiene. Value could be reclaimed from this material, however, by anaerobic digestion to provide a reliable source of heat and electricity for product refrigeration and factory operations. This would also help to reduce spoilage and losses, by reducing the factory's dependence on unreliable centralised power distribution systems, and would thus contribute to waste minimisation in the early stages of this product chain.

\section{$2 \quad$ Materials and methods}

\subsection{Anaerobic digesters}

The first part of the study was carried out in eight continuously stirred tank reactors (CSTR) each with a 5-liter capacity and a 4-liter working volume, and the second part in six 2-liter CSTR digesters each with a 1.5-liter working volume. All digesters were constructed of PVC tube with gas-tight top and bottom plates. The top plate was fitted with a gas outlet, a feed port sealed with a rubber bung, and a draught tube liquid seal through which an asymmetric bar stirrer was inserted with a $40 \mathrm{rpm}$ motor mounted directly on the top plate (Figure 1). Temperature was controlled at $35{ }^{\circ} \mathrm{C}$ by circulating water from a thermostatically-controlled bath through a heating coil around the digesters. Biogas was measured using tipping-bucket gas counters with continuous datalogging [24] and all gas volumes reported are corrected to standard temperature and pressure (STP) of $0{ }^{\circ} \mathrm{C}$ and $101.325 \mathrm{kPa}$. Semi-continuous operation was achieved by removing digestate through an outlet port in the base before adding feed via the feed port. During this process a small amount of atmospheric air enters the headspace but in insufficient quantities to affect the redox conditions in the digester: any nitrogen detected in the gas composition is corrected for, as this is not normally produced as a result of the digestion process. Feeding was done on a daily basis throughout the experimental period with regular checks to ensure a constant level was maintained in the digesters. The 5-liter digesters were initially seeded with digestate from a digester treating municipal wastewater biosolids at Millbrook Wastewater Treatment plant, Southampton, UK.

\subsection{Digester feed and supplements}

The vegetable waste (VW) consisted of extra fine beans $11.6 \%$, fine beans $23.3 \%$, runner beans $21.6 \%$, stringless beans $18.2 \%$, baby corn $18.8 \%$, carrot $3.5 \%$, and broccoli $3.0 \%$, on a wet weight (WW) basis. These were macerated in a grinder (series 526, Imperial Machine Co $\mathrm{Ltd}$, UK), then frozen in 4-liter batches and defrosted and stored at $4{ }^{\circ} \mathrm{C}$ before use. Cosubstrates used were card packaging (wet ground with added tap water) obtained from Alton materials reclamation facility (Hampshire, UK); and cattle slurry from a dairy farm (Rownhams, Southampton, UK).

In the 4-liter trial the TE solution proposed by Gonzalez-Gil et al. [25] was added at the start of the experiment to each digester in the proportion of $1 \mathrm{~mL} \mathrm{~L}^{-1}$, and then weekly in the same proportion based on the volume of feedstock added. In the 1.5-liter trial a modified TE solution was used which contained the following $\left(\mathrm{g} \mathrm{L}^{-1}\right): \mathrm{FeCl}_{2} \cdot 4 \mathrm{H}_{2} \mathrm{O}, 35.5 ; \mathrm{CoCl}_{2} \cdot 6 \mathrm{H}_{2} \mathrm{O}$, 4.034; $\mathrm{MnCl}_{2} . \quad 4 \mathrm{H}_{2} \mathrm{O}, \quad 0.36 ; \mathrm{AlCl}_{3} \cdot 6 \mathrm{H}_{2} \mathrm{O}, \quad 0.894 ; \mathrm{H}_{3} \mathrm{BO}_{3}, \quad 0.571 ; \mathrm{ZnCl}_{2}, \quad 20.833 ;$ 
$\left(\mathrm{NH}_{4}\right)_{6} \mathrm{Mo}_{7} \mathrm{O}_{24} .4 \mathrm{H}_{2} \mathrm{O}, 0.184 ; \mathrm{CuCl}_{2} .2 \mathrm{H}_{2} \mathrm{O}, 0.268 ; \mathrm{NiCl}_{2} .2 \mathrm{H}_{2} \mathrm{O}, 2.825 ; \mathrm{Na}_{2} \mathrm{SeO}_{3}, 0.219 ;$ $\mathrm{Na}_{2} \mathrm{WO}_{4} \cdot 2 \mathrm{H}_{2} \mathrm{O}, 0.18$. This was supplemented in the same way as in the 4-liter digesters.

\subsection{Analytical methods}

Total solids (TS) and volatile solids (VS) were measured according to Standard Method 2540 $\mathrm{G}$ [26]. pH was determined using a Jenway 3010 meter (Bibby Scientific Ltd, UK) with a combination glass electrode, calibrated in buffers at $\mathrm{pH} \mathrm{4,} 7$ and 9.2 (Fisher Scientific, UK). Alkalinity was measured by titration using $0.25 \mathrm{~N} \mathrm{H}_{2} \mathrm{SO}_{4}$ to endpoints of $\mathrm{pH} 5.7$ and 4.3 [27]. Ammonia and Total Kjeldahl Nitrogen (TKN) were determined using a Kjeltech block digestion and steam distillation unit according to the manufacturer's instructions (Foss Ltd, UK). Elemental composition $(\mathrm{C}, \mathrm{H}, \mathrm{N})$ was analysed using a FlashEA 1112 Elemental Analyzer (Thermo Finnigan, Italy) according to the manufacturer's instructions with methionine, L-cystine and sulfanilamide as standards. Neutral detergent fibre (NDF), acid detergent fibre (ADF) and acid detergent lignin (ADL) were analysed using the FiberCap ${ }^{\mathrm{TM}}$ system [28]. Calorific value (CV) was measured using a bomb calorimeter (CAL2k, Digital Data Systems Ltd, South Africa). Trace elements were measured using ICP-MS (Severn Trent Laboratory Limited, UK) after acid digestion in aqua regia. Volatile fatty acid (VFA) concentrations were quantified in a Shimazdu 2010 gas chromatograph (Shimadzu, UK) using a flame ionization detector and a capillary column type SGE BP 21 with helium as the carrier gas at a flow of $190.8 \mathrm{~mL} \mathrm{~min}^{-1}$, with a split ratio of 100 giving a flow rate of $1.86 \mathrm{~mL}$ $\mathrm{min}^{-1}$ in the column and a $3.0 \mathrm{~mL} \mathrm{~min}^{-1}$ purge. The GC oven temperature was programmed to increase from 60 to $210{ }^{\circ} \mathrm{C}$ in $15 \mathrm{~min}$, with a final hold time of $3 \mathrm{~min}$. The temperatures of injector and detector were 200 and $250{ }^{\circ} \mathrm{C}$, respectively. Samples were acidified using formic acid. Three standard solutions containing 50,250 and $500 \mathrm{mg} \mathrm{L}^{-1}$ of acetic, propionic, isobutyric, n-butyric, iso-valeric, valeric, hexanoic and heptanoic acids were used for VFA calibration. Biogas composition was measured using a Varian CP-3800 gas chromatograph (Varian, UK) with a gas sampling loop and thermal conductivity detector with argon as the carrier gas at a flow of $50 \mathrm{~mL} \mathrm{~min}^{-1}$. The $\mathrm{GC}$ was fitted with a Hayesep $\mathrm{C}$ column and a molecular sieve $13 \times\left(80-100\right.$ mesh) operating at a temperature of $50{ }^{\circ} \mathrm{C}$, and calibrated using a standard gas containing $35 \% \mathrm{CO}_{2}$ and $65 \% \mathrm{CH}_{4}$ (BOC, UK). Biochemical methane potential (BMP) tests were carried out in duplicate with 3 inoculum-only controls and 3 positive controls of cellulose (Sigma-Aldrich, UK).

\subsection{Stoichiometric energy potential calculations}

The theoretical gas composition based on elemental analysis was calculated using the Buswell equation [29]:

$\mathrm{C}_{c} \mathrm{H}_{h} \mathrm{O}_{o} \mathrm{~N}_{n} \mathrm{~S}_{s}+1 / 4(4 c-h-2 o+3 n+2 s) \mathrm{H}_{2} \mathrm{O}=1 / 8(4 c-h+2 o+3 n+2 s) \mathrm{CO}_{2}+1 / 8(4 c+h-2 o-3 n$ - $2 s) \mathrm{CH}_{4}+n \mathrm{NH}_{3}+\mathrm{sH}_{2} \mathrm{~S}$

Theoretical calorific value (TCV) was calculated using the Du Long equation in accordance with PD CEN/TR 13767 [30]:

$T C V=(34.1 C+102 H+6.3 N+19.1 S-9.85 O) / 100$

\section{$3 \quad$ Results and discussion}

\subsection{Feedstock characteristics}


The TS and VS contents of the VW were 77.4 and $72.4 \mathrm{~g} \mathrm{~kg}^{-1} \mathrm{WW}$, respectively. TKN was $3.46 \mathrm{~g} \mathrm{~N} \mathrm{~kg}^{-1} \mathrm{WW}$, phosphorus $0.86 \mathrm{~g} \mathrm{P} \mathrm{kg}^{-1} \mathrm{WW}$ and potassium $2.44 \mathrm{~g} \mathrm{~K} \mathrm{~kg}^{-1} \mathrm{WW}$. Elemental composition was $\mathrm{C} 51.11 \%, \mathrm{~N} 4.63 \%, \mathrm{H} 6.76 \%$ and $\mathrm{O} 37 \%$ on a VS basis, with a $\mathrm{C} / \mathrm{N}$ ratio of $11: 1$. Fibre content was $13.16 \%$ cellulose, $2.56 \%$ hemicellulose and $8.16 \%$ lignin on a VS basis. The $\mathrm{pH}$ was 5.77 , and the calorific value was $20.58 \mathrm{MJ} \mathrm{kg}^{-1} \mathrm{VS}$. The calorific value calculated from the elemental composition of the VW using the Du Long equation was $20.99 \mathrm{MJ} \mathrm{kg}^{-1} \mathrm{VS}$ which is in good agreement with the value measured by bomb calorimetry. The result therefore supports the accuracy of the elemental composition analysis. TS and VS contents of the supplements and co-substrates were 883.0 and 667.0, 89.0 and 66.9, and 202.0 and $165.5 \mathrm{~g} \mathrm{~kg}^{-1} \mathrm{WW}$, for yeast extract, cattle slurry and card packaging respectively.

\subsection{4-liter digestion trial}

Digesters D1-8 were fed with VW initially at an OLR of $0.7 \mathrm{~g} \mathrm{VS} \mathrm{L}^{-1}$ day $^{-1}$ for 14 days. Loadings on pairs of digesters were then incrementally raised to give OLR of 2, 3, 4 and $5 \mathrm{~g}$ VS L ${ }^{-1}$ day $^{-1}$, equivalent to HRTs of 40, 25.6, 19 and 15 days respectively. The pair of digesters at OLR 2 (D1 and D2) operated for 257 days. During this time they remained stable for 120 days and then showed a decrease in $\mathrm{pH}$ from 7.5 to 7.2 , a reduction in gas production and an increase in VFA concentrations (Figure 2a-c). On day 137 additional supplementation of the trace element tungsten (not present in the formula of Gonzalez-Gil et al. [25]) was added to D1 and D2 to give a concentration of $0.1 \mathrm{mg} \mathrm{W} \mathrm{L}^{-1}$ above the existing level in the digester. This was achieved by initially adding $1 \mathrm{~mL}$ of a $0.18 \mathrm{~g} \mathrm{~L}^{-1} \mathrm{Na}_{2} \mathrm{WO}_{4} \cdot 2 \mathrm{H}_{2} \mathrm{O}$ solution to each digester, followed by supplementation with $0.04 \mathrm{~mL}$ of this solution every 7 days to compensate for washout. Digester D2 also received a daily supplement of $4 \mathrm{~mL}$ of a $200 \mathrm{~g}$ TS $\mathrm{L}^{-1}$ yeast extract (YE) solution (Merck, Darmstadt, Germany). In both cases gas production recovered and $\mathrm{pH}$ increased to 7.6-7.7. The slightly higher biogas yield in D2 can be attributed to the yeast extract addition. Average parameter values for the stable operating period at the end of the run were: methane yield $0.345 \mathrm{~L} \mathrm{~g}^{-1} \mathrm{VS}_{\text {added }}$; digestate VS $15.5 \mathrm{~g} \mathrm{~kg}^{-1}$; VS destruction 81.3\%; total ammonia nitrogen 1.73 and $2.29 \mathrm{~g} \mathrm{~kg}^{-1}$ in D1 and D2 respectively; biogas methane content $53.4 \%$ and Ripley ratios [27] of $\sim 0.3$. Based on a lower heat calorific value (LHV) of $35.82 \mathrm{MJ} \mathrm{m}^{-3} \mathrm{CH}_{4}$, the energy recovered in the form of methane represents $68.6 \%$ of the measured calorific value of the vegetable waste.

In the second pair of digesters (D3 and D4) the OLR was increased to $3 \mathrm{~g} \mathrm{VS} \mathrm{L}^{-1}$ day $^{-1}$ after 30 days and remained stable with an average specific methane yield of $0.31 \mathrm{~L} \mathrm{~g}^{-1}$ VS added until around day 80 at which point there was a drop in gas production, a rapid fall in $\mathrm{pH}$ and accumulation of VFA (Figure 2d-f). Various attempts were made to recover this pair of digesters by stopping feeding and then resuming at a reduced loading; all these attempts failed. Digester D4 received additional buffering on day 91 by the addition of $3 \mathrm{~g}$ of ammonium bicarbonate. To maintain $\mathrm{pH}$, however, a cycle of intermittent feeding and alkali additions was necessary which resulted in a series of $\mathrm{pH}$ oscillations and a generally decreasing performance. This run was terminated on day 133.

The OLR in D5-8 was increased from 0.7 to $4 \mathrm{~g} \mathrm{VS} \mathrm{L}^{-1}$ day $^{-1}$ over a period of 52 days, after which time all four digesters were suffering from low $\mathrm{pH}$ values and poor gas production and were stopped on day 69. The four digesters D5-8 were emptied and re-seeded with fresh inoculum from the Millbrook digester (Southampton, UK) and feeding started at an OLR of 3 $\mathrm{g} \mathrm{VS} \mathrm{L}^{-1}$ day $^{-1}$. Between days 85-92 the OLR was gradually increased to $3.4 \mathrm{~g} \mathrm{VS} \mathrm{L}^{-1}$ day $^{-1}$ but this resulted in a decline in gas production and $\mathrm{pH}(<7)$. From this and the previous 
results it appeared that operation at or above an OLR of $3 \mathrm{~g} \mathrm{VS} \mathrm{L}^{-1}$ day $^{-1}$ would probably not be achievable without supplementation or the use of co-substrates. Digesters D5 and D6 were therefore given chemical supplements aimed at enhancing digester alkalinity, while in digesters D7 and D8 card packaging and cattle slurry were added as co-substrates to improve the $\mathrm{C} / \mathrm{N}$ ratio and possibly provide additional trace elements. Digester D5 was given ammonium bicarbonate and sodium bicarbonate daily $\left(2.5 \mathrm{~g} \mathrm{NH}_{4} \mathrm{HCO}_{3}\right.$ and $\left.2.5 \mathrm{~g} \mathrm{NaHCO}_{3}\right)$. Digester D6 received an additional daily $5 \mathrm{~g}$ of $\mathrm{NaHCO}_{3}$. Digester D7 was fed on $127 \mathrm{~g} \mathrm{VW}$ $\left(\mathrm{OLR}=2.3 \mathrm{~g} \mathrm{VS} \mathrm{L}^{-1} \mathrm{day}^{-1}\right)$ and $63 \mathrm{~g}$ cattle slurry $\left(\mathrm{OLR}=1.1 \mathrm{~g} \mathrm{VS} \mathrm{L}^{-1}\right.$ day $\left.^{-1}\right)$ to give a combined OLR of $3.4 \mathrm{~g} \mathrm{VS} \mathrm{L}^{-1}$ day $^{-1}$. Digester D8 was fed on $92 \mathrm{~g}$ VW feedstock $(1.67 \mathrm{~g} \mathrm{VS}$ $\mathrm{L}^{-1}$ day $\left.^{-1}\right)$ to $20 \mathrm{~g}$ card packaging $\left(0.83 \mathrm{~g} \mathrm{VS} \mathrm{L}^{-1}\right.$ day $\left.^{-1}\right)$, giving a combined OLR of $2.5 \mathrm{~g} \mathrm{VS}$ $\mathrm{L}^{-1}$ day $^{-1}$.

Chemical supplementation by adding both $\mathrm{NH}_{4} \mathrm{HCO}_{3}$ and $\mathrm{NaHCO}_{3}$ or $\mathrm{NaHCO}_{3}$ alone to maintain alkalinity showed no sustainable beneficial effect, with $\mathrm{pH}$ and gas production continuing to decline rapidly as shown in Figure $3 \mathrm{a}$, and VFA concentrations reaching 15-20 $\mathrm{g} \mathrm{L}^{-1}$. The chemical supplementation trial was terminated on day 133 .

When D7 and D8 were fed on cattle slurry and card packaging as co-substrates the downward trends in performance were reversed, as shown in Figure $3 \mathrm{~b}, 3 \mathrm{~d}$ and $3 \mathrm{f}$. The $\mathrm{pH}$ stabilised around 7.4, accumulated VFA was consumed resulting in concentrations of $<1000 \mathrm{mg} \mathrm{L}^{-1}$ by the end of the trial, and specific gas production stabilised at 0.258 and $0.277 \mathrm{~L} \mathrm{CH}_{4} \mathrm{~g}^{-1} \mathrm{VS}$ added for the co-substrate mixes containing card packaging and cattle slurry respectively.

Results from trace element analysis on digestate from selected digesters on day 164 (approximately 3 HRT after re-seeding) are shown in Table 1. The data showed that in digesters D3 and D6, tungsten concentrations were below the detection limit of $10 \mu \mathrm{g} \mathrm{L}^{-1}$. In D1 and D2 the measured tungsten concentrations of 0.10 and $0.14 \mathrm{mg}^{-1}$ were in good agreement with the intended supplementation value, indicating good analytical accuracy. It is also noteworthy that in D7 and D8, the two digesters with co-substrates, the tungsten concentrations were relatively high. Since no tungsten was supplemented, the extra tungsten can only have come from the co-substrates. This finding supports the importance of tungsten in maintaining the anaerobic process. The requirement for tungsten of methanogens growing on $\mathrm{H}_{2}$ and $\mathrm{CO}_{2}$ has long been known [31], and this element has also been reported to play a significant role in propionate degradation [32, 33]. Despite this, however, tungsten is not included in most of the commonly-used trace element recipes found in the literature.

In digester D1 which received YE addition Cobalt and Selenium concentrations were found to be higher than in the other digesters, suggesting that YE was an additional source for these two trace elements.

\subsection{5-liter digestion trial}

The second part of the study used mixed digestate taken from digesters D1 and D2 as an inoculum for six 1.5-liter working volume digesters (A1-6), to ensure that a healthy and wellacclimated population was carried over from the first trial. These were supplemented as before with the modified TE recipe. All digesters were fed with VW initially at an OLR of 2 $\mathrm{g} \mathrm{VS} \mathrm{L}^{-1}$ day $^{-1}$ for 10 days. The loading on pairs of digesters A1-2 remained at $2 \mathrm{~g} \mathrm{VS} \mathrm{L}^{-1}$ day $^{-1}$, while the OLR on A3-4 was incrementally raised to $3 \mathrm{~g} \mathrm{VS} \mathrm{L}^{-1}$ day $^{-1}$, and on A5-6 to 4 $\mathrm{g} \mathrm{VS} \mathrm{L}^{-1}$ day $^{-1}$, equivalent to HRTs of 40, 26.3 and 20 days respectively. 
All six digesters achieved their target OLRs, with digestion continuing stably for at least 3 HRT. Specific methane production was between $0.348-0.353 \mathrm{~L} \mathrm{~g}^{-1} \mathrm{VS}$, and volumetric biogas and methane productions are shown in Figure 4. $\mathrm{pH}$ in all digesters remained at $\sim 7.5$ throughout the experimental period. Alkalinity in all digesters was sufficiently high with a Ripley ratio consistently below 0.4 indicating stable operation. There was no build-up of longer chain VFA such as iso-butyric, n-butyric, iso-valeric, valeric, hexanoic, and heptanoic acids but there was some accumulation in acetic acid at the start of the experimental period (Figure 5). The concentration fell as the experiment continued, however, and stabilised at $<50$ $\mathrm{mg} \mathrm{L}^{-1}$ irrespective of the OLR. This brief elevation in acetic acid happened in all 6 digesters and was therefore possibly as a result of an initial adaption. Average values for operational parameters are shown in Table 2.

The use of the modified trace element recipe with the inclusion of tungsten and higher concentrations of other known essential elements allowed stable operation at OLR higher than those achieved in previous studies using similar FVW feedstocks $[4,9,34,35]$.

\subsection{BMP test}

Table 3 and Figure 6 show the cumulative net specific methane production over a 28-day test period for the VW feedstock and YE used in the first semi-continuous trial. The BMP results showed very good agreement between duplicate samples, with a specific methane yield of $0.352 \mathrm{~L} \mathrm{~g}^{-1}$ VS added. This is equivalent to $25.5 \mathrm{~m}^{3} \mathrm{CH}_{4}$ per wet tonne, which reflects the high water content of the material and is fairly typical of literature values $[4,9,12]$. The semi-continuous trials achieved $\sim 99 \%$ of the BMP despite the relatively short HRT, confirming both the rapid biodegradability of the substrate and the BMP results, which showed most of the gas production occurring in the first 10 days (Figure 6).

The BMP value for the YE confirmed that this would account for the increased biogas yield in the 4-liter digestion trial; YE addition may also have contributed to improved digestion stability. Speece [15] demonstrated the stimulatory effects of yeast extract on methanogenesis and concluded that its trace metal constituents, especially the significant amount of nickel, were the cause of the stimulation. In the trace element analysis of the digestate (Table 1), it is noticeable that the cobalt and selenium concentration in the YE supplemented digester D2 was more than double that in D1, suggesting that this was attributable to the supplementation.

\subsection{Digester stability during semi-continuous trials}

It has been suggested that failures in the anaerobic digestion of vegetable wastes are due to rapid hydrolysis and the subsequent build-up of VFA [36, 37]. If the failures were simply due to rapid acidification as suggested, however, the effects should be apparent from an early stage; yet the digesters in the 4-liter trial only started to show stress after relatively stable operation for a fairly long period (approximately $3 \mathrm{HRT}$ ). This study used the trace element solution of Gonzalez-Gil et al. [25], but it is possible that the concentrations of some of the components were not high enough to satisfy the enzyme demands at the higher OLR applied. It is also likely that there was a washout of tungsten to a critical level and supplementation of this restored the digesters to normal operation at the lower loading. It is therefore likely that tungsten was washed out at an earlier stage at higher loadings due to the shorter HRT, but it is also possible that other trace elements might have been deficient or unavailable. 
The experiments carried out in 1.5-liter digesters with the modified TE solution achieved good stability and performance even at very high OLR, indicating that the earlier failures were likely to have been as a result of trace element deficiency rather than washout of the microbial population.

The results suggest that digestion of vegetable waste without trace element supplementation is likely to result in failure particularly at higher loadings. This may be because the trace element concentrations in the vegetable wastes are very low, or the availability to microorganisms is limited. The trace element solution of Gonzalez-Gil et al. [25] contains EDTA as a chelating agent. This is known to have an adverse effect on metal bioavailability, which may be persistent due to its non-biodegradability under both aerobic and anaerobic conditions [38]. The modified the TE recipe was devised to address these problems by using higher concentrations, eliminating the use of EDTA and including the missing element W. The results in the 1.5-liter experiment demonstrated the success of these modifications.

\section{Conclusions}

In this study, vegetable waste could not be used as the sole substrate for anaerobic digestion without suitable trace elements supplementation. Digesters failed after approximately 3 HRT as a result of the build-up of volatile fatty acids and reduction in $\mathrm{pH}$. These changes could not be compensated for in the long term by the use of chemical buffer solutions. The use of a trace element solution according to Gonzalez-Gil et al. [25] allowed stable digestion at a low loading of $2 \mathrm{~g} \mathrm{VS} \mathrm{L}^{-1}$ day $^{-1}$ but the recommended dose may have been insufficient to satisfy trace element requirements when higher loadings were applied. The formulation was also shown to be deficient in tungsten and supplementation with this element was required even at low OLR. An improved TE recipe excluding EDTA and containing a higher concentration of elements allowed stable operation at OLR of $4 \mathrm{~g} \mathrm{VS} \mathrm{L}^{-1}$ day $^{-1}$. The use of yeast extract improved gas production by adding a further carbon source with a high BMP value, and also possibly by contributing additional cobalt and selenium. Using card packaging and cattle slurry as co-substrates proved to be an effective means of restoring stable operating conditions. The current study demonstrated that anaerobic digestion provides an ideal method of energy recovery from vegetable wastes with a high water content, as $68.6 \%$ of the measured calorific value can be recovered in the form of methane. Operation of the digestion process is feasible providing careful attention is paid to supplementation of the feedstock material with trace elements so as to maintain the correct concentration within the digester.

\section{Acknowledgements}

The authors would like to acknowledge Biojoule Ltd and the EU FP7 VALORGAS project (Contract 241334) for supporting this work.

\section{References}

[1] Appels, L., Lauwers, J., Degrève, J., Helsen, L., Lievens, B., Willems, K., Van Impe, J., Dewil, R. (2011). Anaerobic digestion in global bio-energy production: Potential and research challenges, Renewable and Sustainable Energy Reviews, 15(9), 4295-4301.

[2] Arvanitoyannis, I. S., and Varzakas, T. H. (2008). Vegetable Waste Treatment: Comparison and Critical Presentation of Methodologies'. Critical Reviews in Food Science and Nutrition, 48(3), 205-247.

[3] Gunaseelan, V. N. (1997). Anaerobic digestion of biomass for methane production: A review. Biomass and Bioenergy, 13(1-2), 83-114. 
[4] Knol, W., Van Der Most, M. M., and De Waart, J. (1978). Biogas production by anaerobic digestion of fruit and vegetable waste. A preliminary study. Journal of the Science of Food and Agriculture, 29(9), 822-830.

[5] Mata-Alvarez, J., Llabrés, P., Cecchi, F., and Pavan, P. (1992). Anaerobic digestion of the Barcelona central food market organic wastes: Experimental study. Bioresource Technology, 39(1), 39-48.

[6] Lane, A. G. (1979). Methane from anaerobic digestion of fruit and vegetable processing waste. Food Technology in Australia, 31, 201-7.

[7] Mata-Alvarez, J., Macé, S., and Llabrés, P. (2000). Anaerobic digestion of organic solid wastes. An overview of research achievements and perspectives. Bioresource Technology, 74(1), 3-16.

[8] Raynal, J., Delgenès, J. P., and Moletta, R. (1998). Two-phase anaerobic digestion of solid wastes by a multiple liquefaction reactors process. Bioresource Technology, 65(1-2), 97-103.

[9] Verrier, D., Roy, F., and Albagnac, G. (1987). Two-phase methanization of solid vegetable wastes. Biological Wastes, 22(3), 163-177.

[10] Hartmann, H., and Ahring, B. K. (2006). Strategies for the anaerobic digestion of the organic fraction of municipal solid waste: an overview. Water Science and Technology, 53(8), 7-22.

[11] Bouallagui, H., Lahdheb, H., Ben Romdan, E., Rachdi, B., and Hamdi, M. (2009). Improvement of fruit and vegetable waste anaerobic digestion performance and stability with co-substrates addition. Journal of Environmental Management, 90(5), 1844-1849.

[12] Lane, A. G. 1984. Laboratory scale anaerobic digestion of fruit and vegetable solid waste. Biomass, 5, 245-259.

[13] Kumar, A., Miglani, P., Gupta, R. K. \& Bhattacharya, T. K. 2006. Impact of Ni(II), $\mathrm{Zn}(\mathrm{II})$ and $\mathrm{Cd}(\mathrm{II})$ on biogassification of potato waste. Journal of Environmental Biology, 27, 61-66.

[14] Climenhaga, M. A. and Banks, C. J. 2008. Anaerobic digestion of catering wastes: effect of micronutrients and retention time. Water Science \& Technology, 57, 687-692.

[15] Speece, R.E., Parkin, G.F. and Gallagher, D. (1983) Nickel stimulation of anaerobic digestion. Water Research 17(6), 677-683.

[16] Florencio, L. (1994) The fate of methanol in anaerobic bioreactors. Proefschrift Wageningen, Florencio, [S.1.].

[17] Osuna, M.B., Zandvoort, M.H., Iza, J.M., Lettinga, G. and Lens, P.N.L. (2003) Effects of trace element addition on volatile fatty acid conversions in anaerobic granular sludge reactors. Environmental Technology 24(5), 573-587.

[18] Worm, P., Fermoso, F.G., Lens, P.N.L. and Plugge, C.M. (2009) Decreased activity of a propionate degrading community in a UASB reactor fed with synthetic medium without molybdenum, tungsten and selenium. Enzyme and Microbial Technology 45(2), 139-145.

[19] Williams, C.M., Shih, J.C.H. and Spears, J.W. (1986) Effect of nickel on biological methane generation from a laboratory poultry waste digester. Biotechnology and Bioengineering 28(11), 1608-1610.

[20] Gonzalez-Gil, G., Jansen, S., Zandvoort, M.H. and van Leeuwen, H.P. (2003) Effect of yeast extract on speciation and bioavailability of nickel and cobalt in anaerobic bioreactors. Biotechnology and Bioengineering 82(2), 134-142.

[21] Gonzalez-Gil, G., Kleerebezem, R. and Lettinga, G. (1999) Effects of Nickel and Cobalt on Kinetics of Methanol Conversion by Methanogenic Sludge as Assessed by On-Line CH4 Monitoring. Appl Environ Microbiol. 65(4), 1789-1793 
[22] Fermoso, F.G., Bartacek, J., Jansen, S. and Lens, P.N.L. (2009) Metal supplementation to UASB bioreactors: from cell-metal interactions to full-scale application. Science of The Total Environment 407(12), 3652-3667.

[23] Sprott, G.D. (1989) Metal Ions and Bacteria. Beveridge, T.J. and Doyle, R.J. (eds), pp. 91-120, John Wiley \& Sons, Inc.

[24] Walker, M., Zhang, Y., Heaven, S., and Banks, C. (2009). Potential errors in the quantitative evaluation of biogas production in anaerobic digestion processes. Bioresource Technology, 100(24), 6339-6346.

[25] Gonzalez-Gil, G., Seghezzo, L., Lettinga, G., and Kleerebezem, R. (2001). Kinetics and mass-transfer phenomena in anaerobic granular sludge. Biotechnology and Bioengineering, 73(2), 125-134.

[26] APHA. (2005). Standard Methods for the Examination of Water and Wastewater, Washington, D.C.

[27] Ripley, L. E., Boyle, W. C., and Converse, J. C. (1986). Improved alkalimetric monitoring for anaerobic-digestion of high-strength wastes. Journal Water Pollution Control Federation, 58(5), 406-411.

[28] Kitcherside, M. A., Glen, E. F., and Webster, A. J. F. (2000). FibreCap: an improved method for the rapid analysis of fibre in feeding stuffs. Animal Feed Science and Technology, 86(1-2), 125-132.

[29] Symons, G.E., Buswell, A.M. (1933). The methane fermentation of carbohydrates. J. Am. Chem. Soc. 55, 2028-2036.

[30] PD CEN/TR 13767 (2004) Characterisation of sludges - Good practice for sludges incineration with and without grease and screenings.

[31] Zellner, G. \& Winter, J. 1987. Growth promoting effect of tungsten on methanogens and incorporation of tungsten-185 into cells. FEMS Microbiology Letters, 40, 81-87.

[32] Plugge, C., Jiang, B., De Bok, F., Tsai, C. \& Stams, A. 2009. Effect of tungsten and molybdenum on growth of a syntrophic coculture of Syntrophobacter fumaroxidans and Methanospirillum hungatei. Archives of Microbiology, 191, 55-61.

[33] Reda, T., Plugge, C. M., Abram, N. J. \& Hirst, J. 2008. Reversible interconversion of carbon dioxide and formate by an electroactive enzyme. Proceedings of the National Academy of Sciences, 105, 10654-10658.

[34] Yang, P. Y., Weitzenhoff, M. H. \& Moy, J. H. 1984. Biogasification of papaya processing wastes. Transactions of the American Society of Agricultural Engineers, 27, 840-843.

[35] Stewart, D., Bogue, M. \& Badger, D. 1984. Biogas production from crops and organic wastes. 2. Results of continuous digestion tests. New Zealand J. Sci., 27, 285-294.

[36] Bouallagui, H., Touhami, Y., Ben Cheikh, R., and Hamdi, M. (2005). Bioreactor performance in anaerobic digestion of fruit and vegetable wastes. Process Biochemistry, 40(3-4), 989-995.

[37] Misi, S. N., and Forster, C. F. (2001). Batch co-digestion of multi-component agrowastes. Bioresource Technology, 80(1), 19-28.

[38] Speece, R. E. (1996). Anaerobic Biotechnology for Industrial Wastewaters, Archae Press, Nashville, Tennessee. 
Table 1. Trace elements level in representative digesters at the end of the trial

\begin{tabular}{lllllll}
\hline Element $\left(\mathrm{mg} \mathrm{I}^{\mathbf{1}}\right)$ & D1 & D2 & D3 & D6 & D7 & D8 \\
\hline Al & 3.58 & 5.50 & 15.61 & 15.14 & - & - \\
$\mathbf{B}$ & 1.94 & 2.35 & 1.53 & 1.68 & - & - \\
$\mathbf{C o}$ & 0.52 & 1.13 & 0.25 & 0.31 & 0.31 & 0.34 \\
$\mathbf{C u}$ & 0.79 & 0.71 & 0.99 & 1.00 & 1.61 & 2.14 \\
$\mathbf{F e}$ & 18.56 & 18.95 & 72.01 & 41.41 & 40.36 & 47.75 \\
$\mathbf{M n}$ & 2.45 & 2.20 & 1.86 & 2.14 & 9.20 & 3.41 \\
$\mathbf{M o}$ & 0.44 & 0.41 & 0.22 & 0.24 & 0.27 & 0.29 \\
$\mathbf{N i}$ & 1.23 & 1.18 & 0.24 & 0.19 & 1.11 & 1.07 \\
$\mathbf{S e}$ & 0.08 & 0.28 & 0.05 & 0.05 & 0.04 & 0.04 \\
$\mathbf{Z n}$ & 8.23 & 7.50 & 2.31 & 2.50 & 5.36 & 5.26 \\
$\mathbf{W}$ & 0.14 & 0.10 & - & - & 0.68 & 2.09 \\
\hline
\end{tabular}


Table 2 Average operational parameters in A1- A6

\begin{tabular}{|c|c|c|c|c|c|c|c|c|c|}
\hline & $\begin{array}{l}\text { Ammonia (g } \\
\left.\mathrm{kg}^{-1}\right) \pm \text { s.d. }\end{array}$ & $\begin{array}{c}\text { Digestate VS } \\
\left(\mathrm{g} \mathrm{VS} \mathrm{kg}^{-1}\right) \\
\pm \text { s.d. }\end{array}$ & $\begin{array}{c}\text { VS } \\
\text { destruction }\end{array}$ & $\begin{array}{l}\text { Daily biogas } \\
\text { (liters) } \pm \text { s.d. }\end{array}$ & $\mathrm{CH}_{4} \%$ & $\mathrm{TA}\left(\mathrm{mg} \mathrm{l}^{-1}\right)$ & $\mathrm{PA}\left(\mathrm{mg} \mathrm{l}^{-1}\right)$ & $\mathrm{IA}\left(\mathrm{mg} \mathrm{l}^{-1}\right)$ & $\begin{array}{c}\text { Specific } \mathrm{CH}_{4}\left(\mathrm{lg}^{-1}\right. \\
\text { VS })\end{array}$ \\
\hline $\mathrm{A} 1$ & $2.39 \pm 0.21$ & $12.9 \pm 0.48$ & $85.3 \%$ & $1.90 \pm 0.10$ & 54.9 & 12127.2 & 9122.0 & 2875.3 & 0.348 \\
\hline A3 & $2.26 \pm 0.09$ & $14.6 \pm 0.40$ & $83.6 \%$ & $2.90 \pm 0.14$ & 54.7 & 11803.7 & 8830.6 & 2816.3 & 0.352 \\
\hline $\mathrm{A} 4$ & $2.22 \pm 0.21$ & $14.3 \pm 0.43$ & $83.9 \%$ & $2.91 \pm 0.15$ & 54.6 & 11988.9 & 9149.5 & 2690.6 & 0.353 \\
\hline A5 & $2.22 \pm 0.06$ & $15.0 \pm 0.70$ & $83.5 \%$ & $3.85 \pm 0.16$ & 54.7 & 11715.8 & 8966.3 & 2629.3 & 0.351 \\
\hline
\end{tabular}

TA: Total Alkalinity

PA: Partial Alkalinity

IA: Intermediate Alkalinity 
Table 3. Specific methane production (BMP test value)

\begin{tabular}{ccc}
\hline Samples & Biogas $\left(\mathrm{m}^{3} \mathrm{~kg}^{-1} \mathrm{VS}\right.$ added $)$ & Methane $\left(\mathrm{m}^{3} \mathrm{~kg}^{-1} \mathrm{VS}\right.$ added $)$ \\
\hline VW 1 & 0.630 & 0.351 \\
VW 2 & 0.622 & 0.353 \\
VW average & $\mathbf{0 . 6 2 6}$ & $\mathbf{0 . 3 5 2}$ \\
\hline YE 1 & 0.589 & 0.398 \\
YE 2 & 0.597 & 0.405 \\
YE average & $\mathbf{0 . 5 9 3}$ & $\mathbf{0 . 4 0 2}$ \\
\hline Cellulose 1 & 0.695 & 0.430 \\
Cellulose 2 & 0.692 & 0.433 \\
Cellulose average & $\mathbf{0 . 6 9 4}$ & $\mathbf{0 . 4 3 2}$ \\
\hline
\end{tabular}




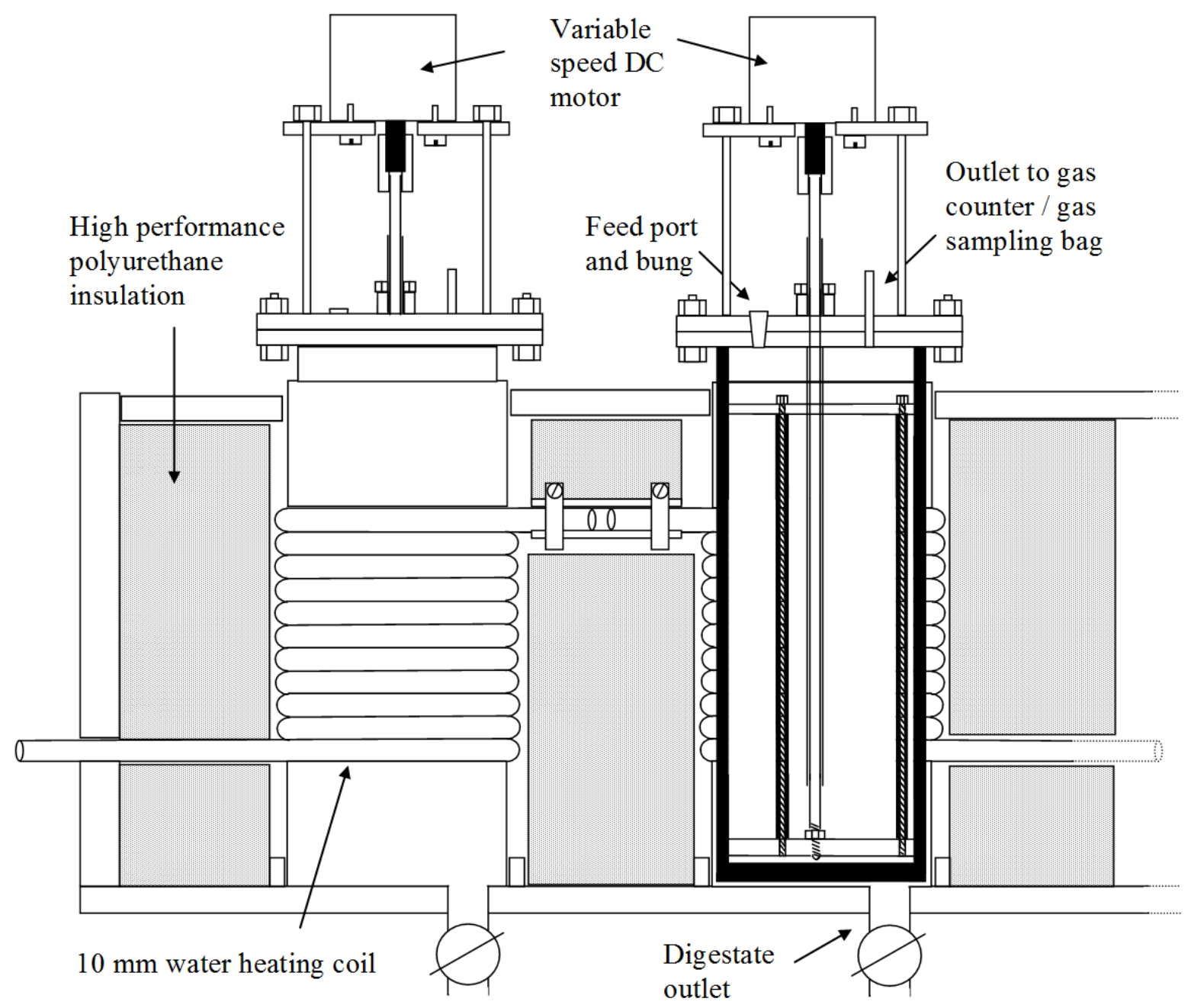

Figure 1. Typical schematic of the 5-liter and 2-liter CSTR digesters used with cross-section showing details of heating and stirring systems. 

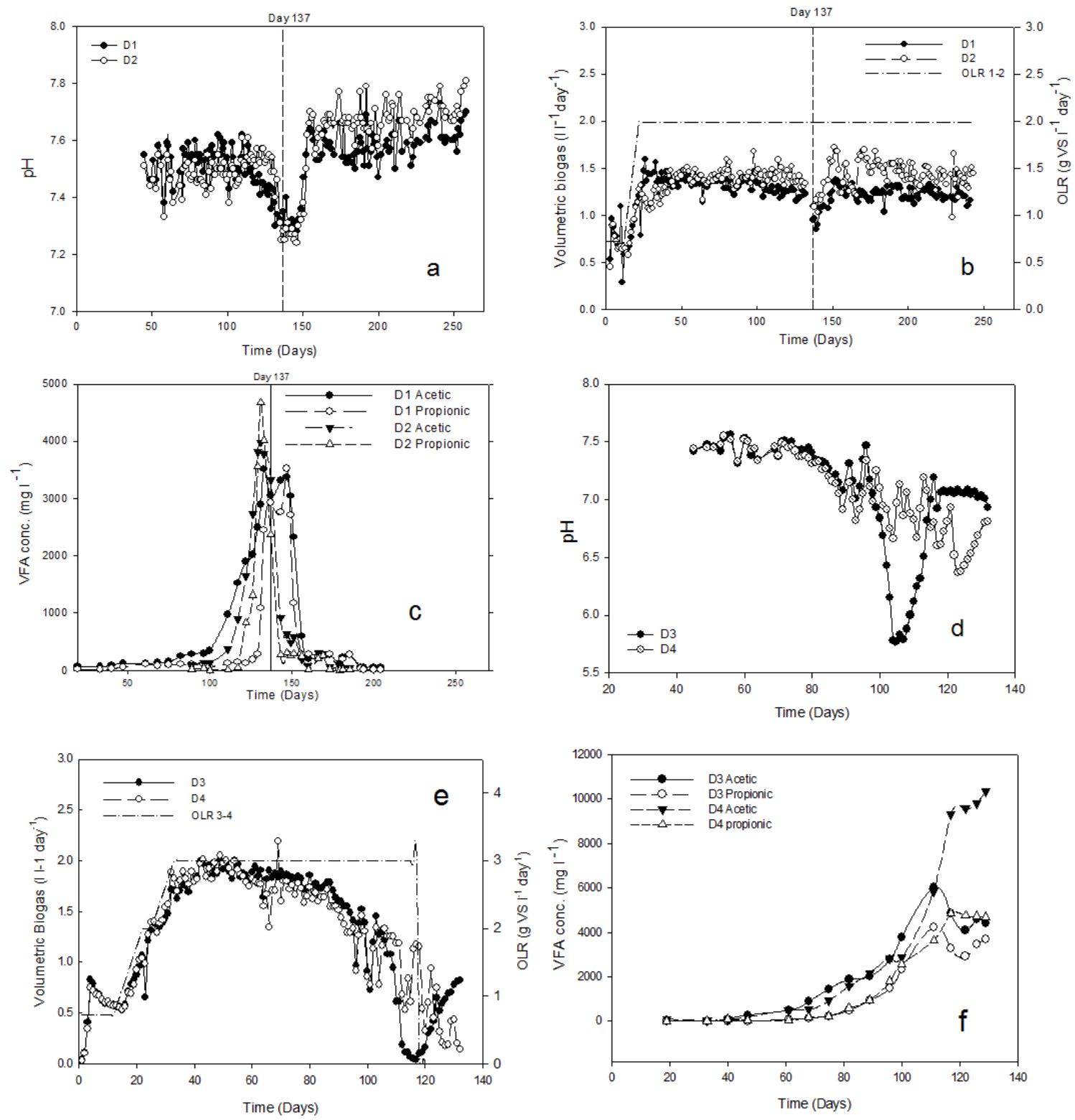

Figure 2. Results from trace elements addition experiment: a) $\mathrm{pH}$ in D1 and D2; b) Daily volumetric biogas production in D1 and D2; c) VFA profile in D1 and D2; d) pH in D3 and D4; e) Daily volumetric biogas production in D3 and D4; f) VFA profile in D3 and D4. 

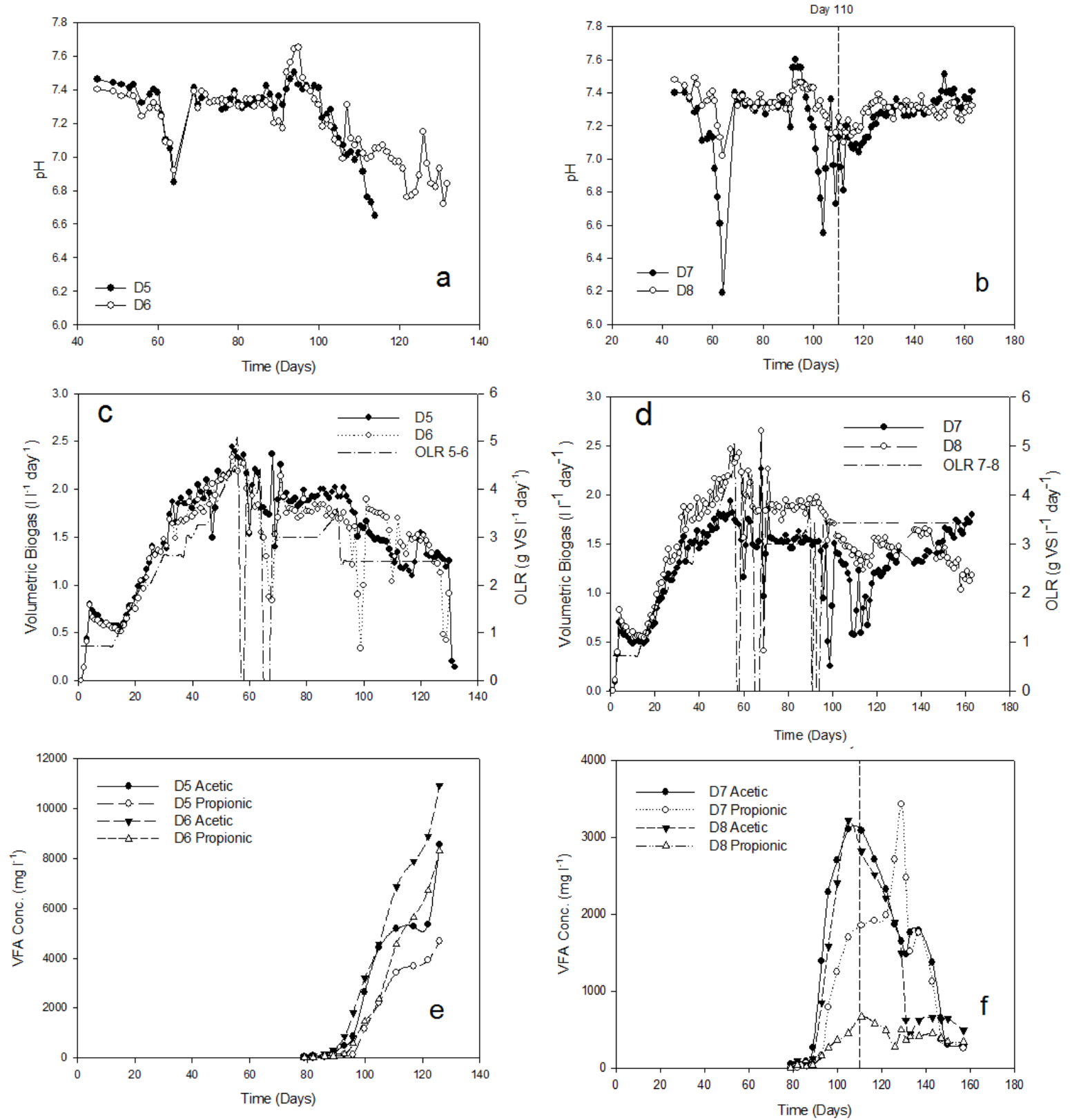

Figure 3. Results from chemical supplementation and co-digestion experiments: a) pH in D5 and D6 before and after addition of chemical supplements from day 94; b) pH in D7 and D8 before and after introduction of card packaging and cattle slurry co-substrates on day 110; c) Daily volumetric biogas production in D5 and D6 before and after addition of chemical supplements from day 94; d) Daily volumetric biogas production in D7 and D8 before and after introduction of co-substrates; e) VFA profiles in D5 and D6; f) VFA profiles in D7 and D8 before and after introduction of co-substrates 

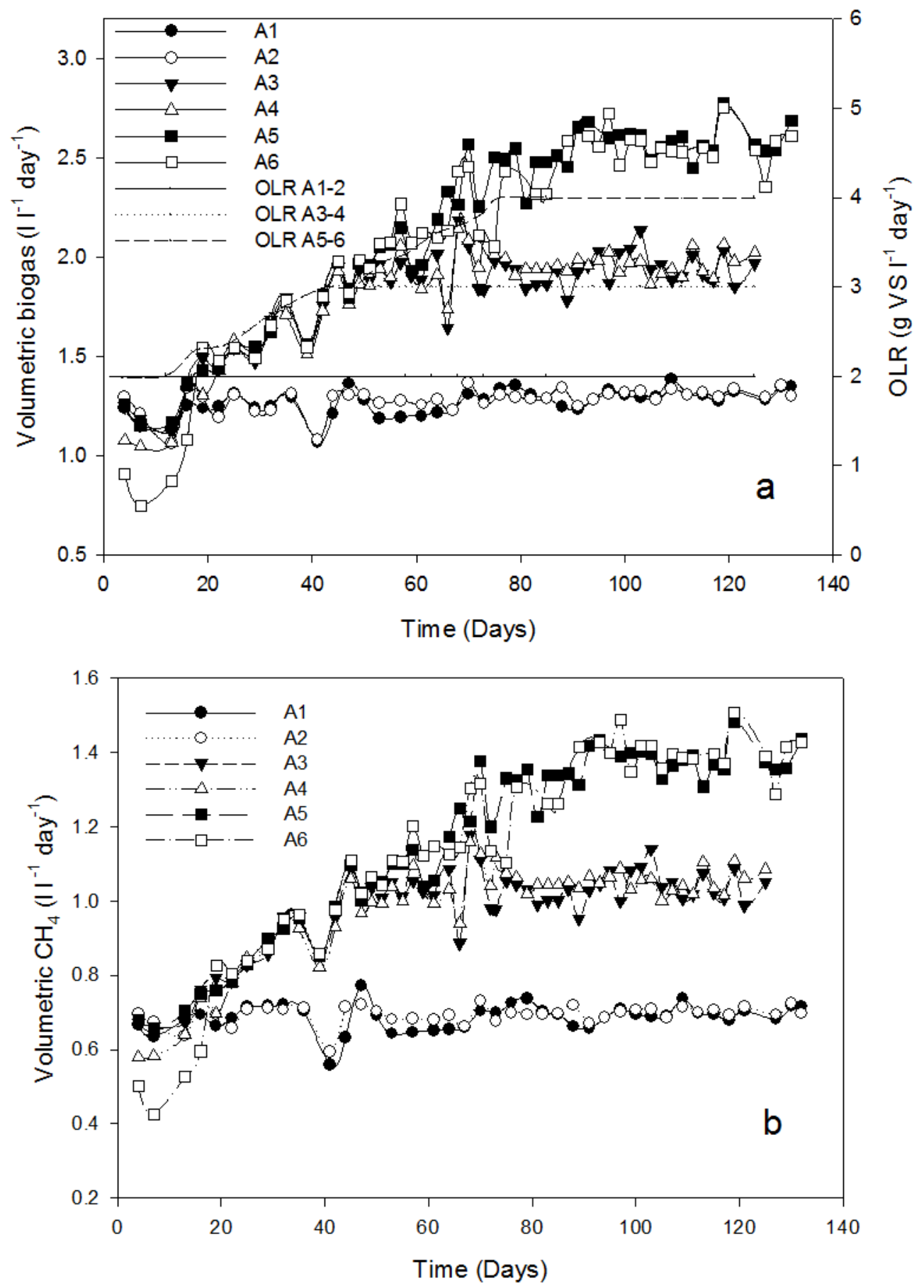

Figure 4. Results from 1.5-liter digester TE supplementation experiment: a) Daily volumetric biogas production in A1-6; b) Daily $\mathrm{CH}_{4}$ production in A1-6 

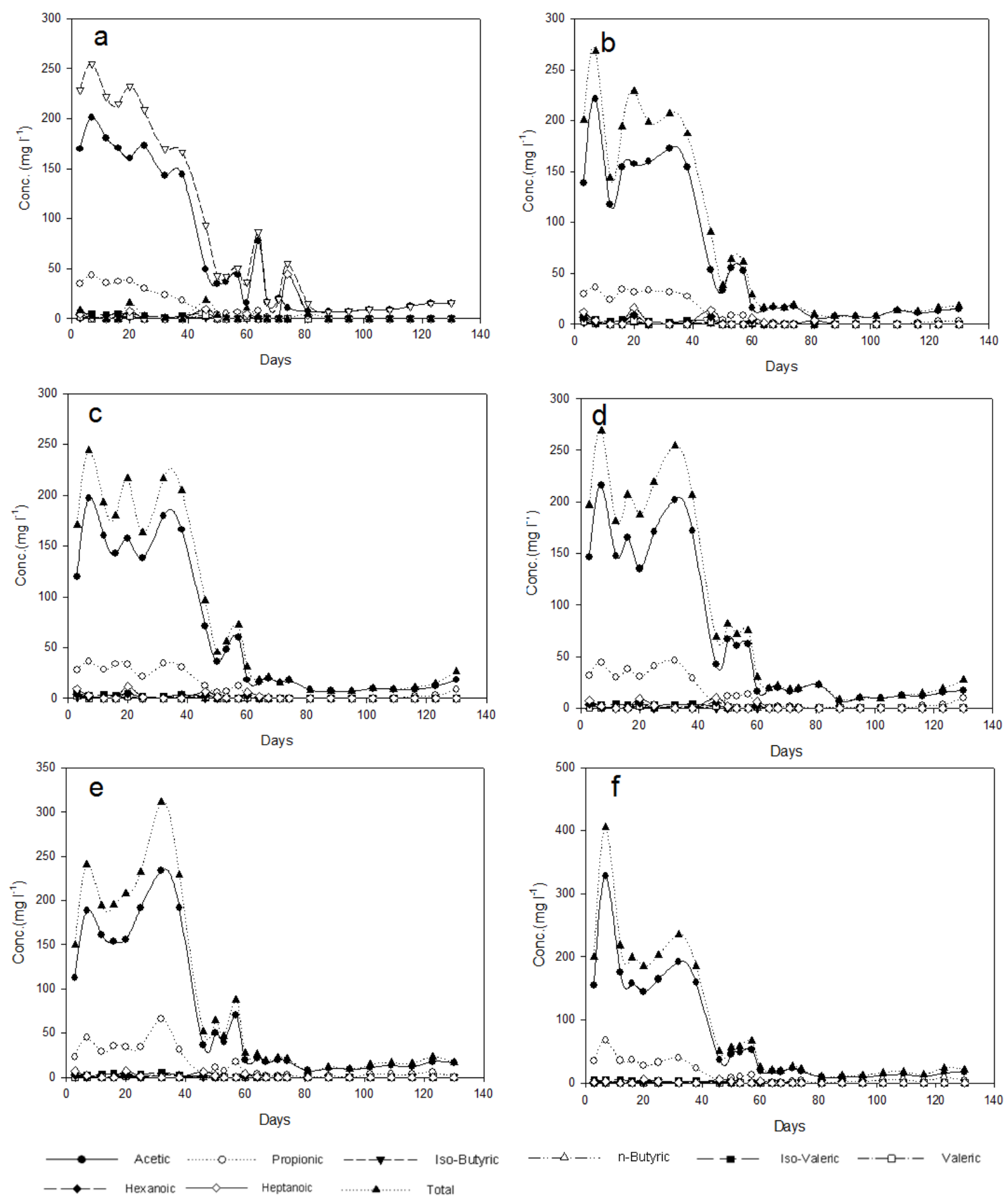

Figure 5. VFA results from 1.5-liter digester experiment, OLR shown in brackets (g VS $1^{-1}$ day $^{-1}$ ): a) A1 (2); b) A2 (2); c) A3 (3); d) A4 (3); e) A5 (4); f) A6 (4). 


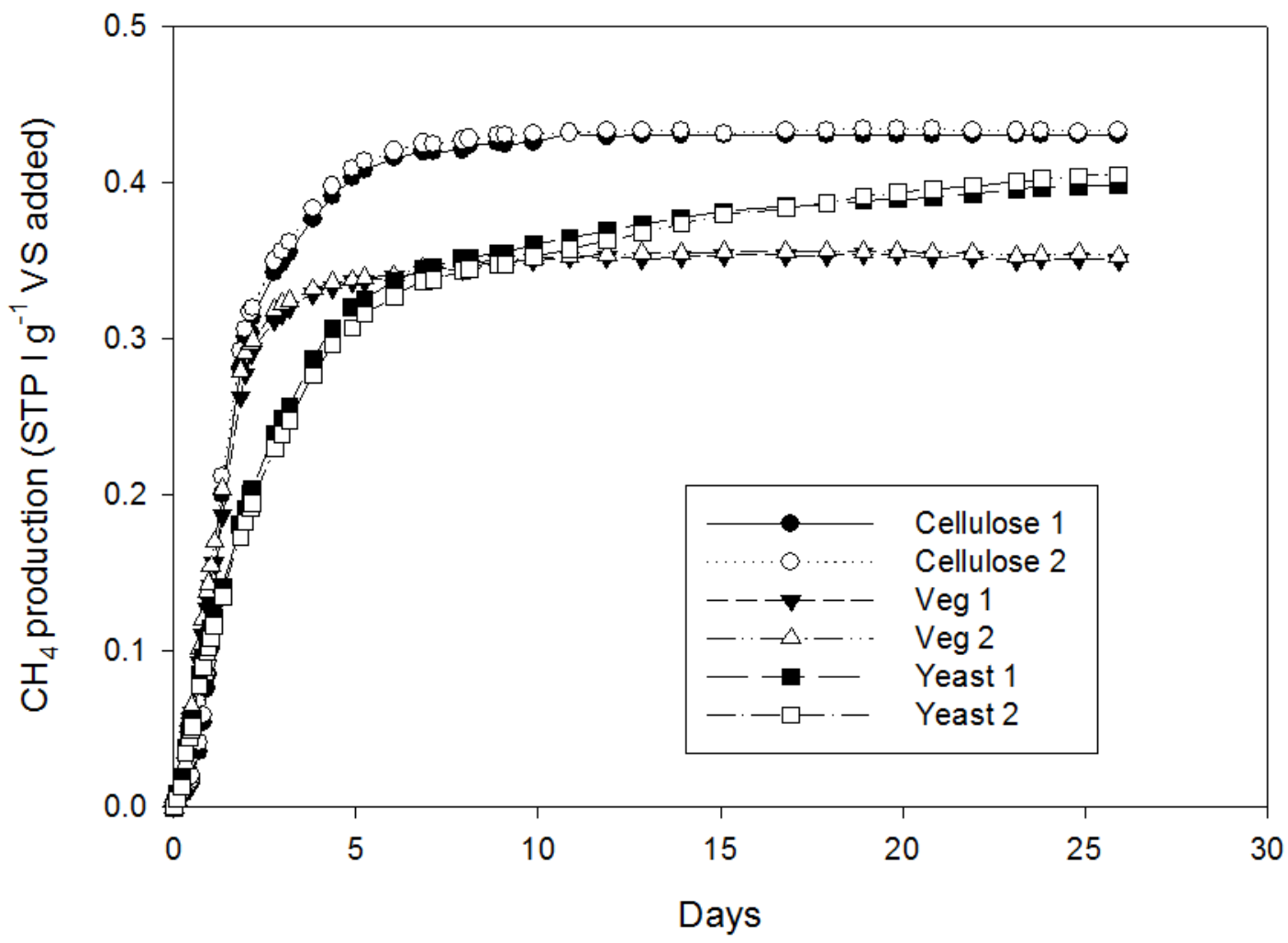

Figure 6. Cumulative net specific methane production of vegetable waste, yeast extract and cellulose positive control. 